KONSTAN
JURNAL FISIKA DAN PENDIDIKAN FISIKA
Volume 4, Nomor 1, Juni 2019
$\begin{array}{r}\text { E-ISSN : 2460-9129 dan P-ISSN : 2460-9110 } \\ \text { http://jurnalkonstan.ac.id/index.php/jurnal }\end{array}$

\title{
PENGEMBANGAN MEDIA PEMBELAJARAN INTERAKTIF MENGGUNAKAN ADOBE FLASH PADA MATERI TERMODINAMIKA
}

\author{
Magdalena Richa Paskah Indrianti ${ }^{1 *}$, Nengah Maharta ${ }^{1}$, Wayan Suana ${ }^{1}$ \\ ${ }^{1}$ Program Studi Pendidikan Fisika Universitas Lampung, Jl. Prof. Dr. Sumantri \\ Brojonegoro No. 1 Kota Bandar Lampung, Lampung, Indonesia
}

\section{Info Artikel}

Sejarah Artikel:

Diterima November 2018

Disetujui Juni 2019

Dipublikasikan Juni 2019

\section{Kata Kunci:}

Penelitian pengembangan, media pembelajaran interaktif, adobe flash, termodinamika

\begin{abstract}
Abstrak
Pengembangan media dalam pembelajaran fisika sangat diperlukan, terutama untuk memahami konsep pada materimateri yang bersifat abstrak. Salah satu upaya yang dilakukan untuk memenuhi kekurangan sumber belajar bagi guru dan siswa dalam memahami konsep termodinamika, telah dikembangkan media pembelajaran interaktif berupa media berbasis TIK. Tujuan penelitian ini adalah mengambangkan media pembelajaran interaktif menggunakan adobe flash pada materi termodinamika dengan menggunakan model pengembangan oleh Sugiyono. Hasil uji ahli menunjukkan bahwa media pembelajaran interaktif menggunakan adobe flash yang dikembangkan telah sesuai dengan teori dan layak digunakan sebagai media pembelajaran. Presentase ketuntasan belajar siswa dengan menggunakan media ini terlihat lebih dari $75 \%$, yaitu sebesar 91,30\%. Uji coba pemakaian dilakukan terhadap siswa kelas XI IPA 4 SMA N 1 Sidomulyo sebagai pengguna menunjukkan hasil uji kemenarikan dengan perolehan skor sebesar 2,93 dengan kualitas menarik, kemudian untuk hasil uji kemudahan diperoleh skor sebesar 3,26 dengan kualitas sangat mudah, dan perolehan skor uji kemanfaatan sebesar 3,34 dengan kualitas sangat bermanfaat. Hasil uji lapangan menunjukkan bahwa media pembelajaran yang dikembangkan efektif digunakan sebagai sumber belajar.
\end{abstract}

\footnotetext{
* Corresponding Author: magdalenaricha95@gmail.com
}

\footnotetext{
Alamat korespodensi:

Gedung Pasca Sarjana Lantai 3 Kampus 2 UIN Mataram, Jl. Gajah Mada 100 Jempong Mataram, Indonesia Email: jurnalkonstan@uinmataram.ac.id
} 


\section{PENDAHULUAN}

Media pembelajaran merupakan salah satu kompnen yang berperan penting dalam proses pembelajaran. Menurut Gerlach dan Ely dalam Arsyad [1] menyatakan, media apabila dipahami secara garis besar adalah manusia, materi, atau kejadian yang membangun kondisi yang membuat siswa mampu memperoleh pengetahuan, keterampilan, atau sikap. Setyono [2] menyatakan bahwa media pembelajaran adalah media yang digunakan sebagai alat bantu dalam proses pembelajaran serta sarana pembawa pesan dari sumber belajar ke penerima pesan belajar (siswa), sehingga dapat merangsang perhatian, minat, pikiran, dan perasaan siswa dalam kegiatan belajar mengajar untuk mencapai tujuan belajar. Hal inilah yang mendasari bahwa media pembelajaran harus dimanfaatkan dengan baik dan benar dalam proses pembelajaran. Jika media pembelajaran dimanfaatkan dengan baik dan benar maka tercipta pembelajaran interaktif di kelas sehingga proses pembelajaran menjadi lebih menarik dan efektif.

Beberapa hasil penelitian mengungkapkan bahwa pembelajaran yang dilakukan pada materi yang bersifat abstrak masih monoton sehingga siswa mengalami kesulitan untuk memahami konsep materi yang bersifat abstrak. Hal ini selajan dengan penelitian pendahuluan yang dilakukan oleh peneliti di SMA N 1 Sidomulyo. Penggunaan media pembelajaran untuk menjalaskan materi yang bersifat abstrak masih belum dilakukan dalam proses pembelajran terutama untuk materi termodinamika. Guru lebih sering menjelaskan materi termodinamika menggunakan cara konvensional menggunkaan metode ceramah.

Berdasarkan hasil angket yang diberikan kepada siswa sebanyak 97,29\% siswa mengalami kesulitan dalam mempelajari fisika terutama untuk materi yang berifat abstrak. Hasil angket menunjukkan bahwa sebanyak $70,27 \%$ siswa menginginkan pembelajaran yang lebih interakfif menggunkan media pembelajaran agar lebih menarik untuk dipelajari. Oleh karena itu, saat ini guru dituntut untuk lebih kreatif dalam proses pembelajaran dengan memanfaatkan media pembelajaran. Dengan demikian siswa akan menjadi lebih termotivasi lagi dalam pembelajaran fisika khususnya pada materi termodinamika.

Pada era yang serba digital ini, sangat memungkinkan untuk mengembangkan media pembelajaran yang berbasis teknologi informasi dan komunikasi. Banyak program yang dapat digunakan untuk menunjang proses pembelajaran, salah satunya adobe flash. Adobe flash merupakan generasi baru dari program animasi macromedia flash 8 . Pemanfaatan media pembelajaran berbasis adobe flash memiliki banyak kelebihan. Menurut Imunandar [3] kelebihan pada adobe flash yaitu, dapat menampilkan video, animasi, suara, dan hasil akhir mampu dipublikasikan ke dalam bentuk file sesuai dengan kebutuhan pengembang.

Seiring dengan perkembangannya, penelitian dan pengembangan media pembelajaran interaktif telah banyak dilakukan. Salah satunya adalah penelitian yang dilakukan oleh Yusuf [4] yang bertujuan untuk menghasilkan produk media pembelajaran berbasis adobe flash pada pokok bahasan radiasi benda hitam. 


\section{METODE PENELITIAN}

Metode penelitian yang digunakan adalah penelitian dan pengembangan (research and development). Pengembangan yang dilakukan berupa pengembangan media pembelajaran interaktif menggunakan software adobe flash. Prosedur pengambangan produk pada penelitian ini berpedoman pada langkah-langkah penelitian dan pengembangan menurut Sugiyono [5] Terdapat 10 langkah penelitian seperti pada gambar 1.

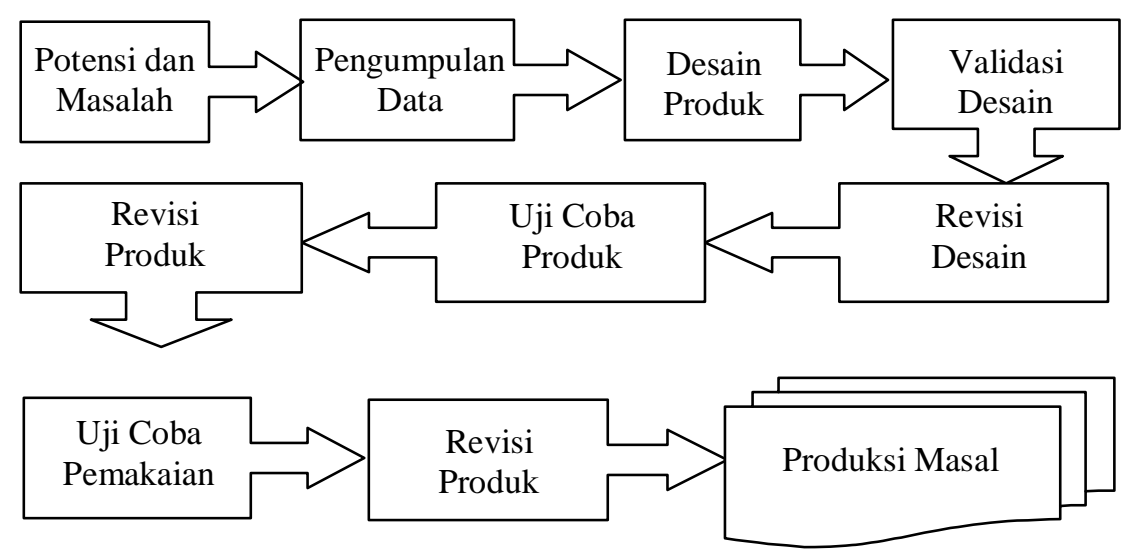

Gambar 1. Langkah-langkah penggunaan metode Research and Development

Subjek uji coba produk penelitian pengembangan terdiri atas ahli desain, ahli isi/materi pembelajaran, uji satu-satu (one for one), dan uji lapangan (field test). Uji ahli validasi ahli dilakukan oleh 2 orang pakar dengan jenjang minimal S2. Selanjutnya untuk uji satu-satu dan uji lapangan dikenakan kepada siswa kelas XI IPA 4 SMA Negeri 1 Sidomulyo, dimana uji satu-satu diambil sampel penelitian yaitu 5 orang siswa yang dapat mewakili populasi target dan uji lapangan dikenakan kepada satu kelas sampel yang dipilih secara acak.

Analisis data berdasarkan instrumen uji ahli dan uji coba terbatas dilakukan untuk menilai sesuai atau tidaknya produk yang dihasilkan sebagai sumber belajar dan media pembelajaran. Instrumen uji ahli desain dan ahli materi memiliki 2 pilihan jawaban sesuai konten pertanyaan, yaitu: "ya" dan "tidak". Revisi dilakukan pada konten pertanyaan yang diberi pilihan jawaban "tidak", atau para ahli memberikan masukan khusus terhadap media/desain yang sudah dibuat. Analisis data berdasarkan instrumen uji coba terbatas dilakukan untuk mengetahui respon dari siswa terhadap media yang sudah dibuat. Instrumen uji coba terbatas ini memiliki 2 pilihan jawaban sesuai konten pertanyaan, yaitu: "ya" dan "tidak". Revisi dilakukan pada konten pertanyaan yang diberi pilihan jawaban "tidak".

Data kemenarikan, kemudahan dan kemanfaatan serta efektivitas media sebagai sumber belajar diperoleh dari uji coba pemakaian kepada siswa sebagai pengguna. Angket respon terhadap pengguna produk memiliki 4 pilihan jawaban sesuai konten pertanyaan, yaitu: "sangat setuju", "setuju", "kurang setuju" dan 
"tidak setuju". Masing-masing pilihan jawaban memiliki skor berbeda yang mengartikan tingkat kesesuaian produk bagi pengguna. Penilaian instrumen total dilakukan dari jumlah skor yang diperoleh kemudian dibagi dengan jumlah total skor, selanjutnya hasilnya dikalikan dengan banyaknya pilihan jawaban. Skor penilaian dari tiap pilihan jawaban ini dapat dilihat dalam Tabel 1

Tabel 1. Skor Penilaian Terhadap Pilihan Jawaban

\begin{tabular}{lr}
\hline \multicolumn{1}{c}{ Pilihan Jawaban } & Skor \\
\hline Sangat Setuju & 4 \\
Setuju & 3 \\
Kurang Setuju & 2 \\
Tidak Setuju & 1 \\
\hline
\end{tabular}

Suyanto (2009)

Instrumen yang digunakan memiliki 4 pilihan jawaban, sehingga skor penilaian total dapat dicari dengan menggunakan rumus:

$$
\text { Skor penilaian }=\frac{\text { Jumlah skor pada instrumen }}{\text { Jumlah nilai total skor tertinggi }} \times 4
$$

Hasil dari skor penilaian tersebut kemudian dicari rata-ratanya dari sejumlah sampel uji coba dan dikonversikan ke pernyataan penilaian untuk menentukan kualitas kemenarikan, kemudahan dan tingkat kemanfaatan produk yang dihasilkan berdasarkan pendapat pengguna. Pengkonversian skor menjadi pernyataan penilaian ini dapat dilihat dalam Tabel 2.

Tabel 2. Konversi Skor Penilaian Menjadi Pernyataan Nilai Kualitas

\begin{tabular}{ccl}
\hline Skor Penilaian & Rerata Skor & Klasifikasi \\
\hline 4 & $3,26-4,00$ & Sangat Baik \\
3 & $2,51-3,25$ & Baik \\
2 & $1,76-2,50$ & Kurang Baik \\
1 & $1,01-1,75$ & Tidak Baik \\
\hline
\end{tabular}

Sedangkan untuk analisis keefektifan media, hasil post-test yang diberikan akan dibandingkan dengan nilai KKM pelajaran fisika kelas XI IPA SMAN 1 Sidomulyo yaitu sebesar 75. Nilai yang diperoleh pada tahap uji coba pemakaian dibandingkan dengan KKM, kemudian dihitung jumlah siswa yang tuntas atau mendapatkan nilai di atas KKM. Apabila hasil belajar dari $75 \%$ siswa yang menggunakan media pembelajaran ini telah tuntas KKM, maka media pembelajaran ini dapat dikatakan media yang efektif untuk digunakan sebagai sumber belajar. 


\section{HASIL DAN PEMBAHASAN}

\section{A. Hasil Penelitian}

Hasil penelitian pengembangan yang dilakukan di SMA Negeri 1 Sidomulyo ini adalah media pembelajaran berbasis TIK pada materi pokok Termodinamika. Analisis kebutuhan dilakukan untuk mengumpulkan informasi dengan membandingkan kondisi sebenarnya dengan kondisi yang ideal yang seharusnya terjadi sejauh mana diperlukannya media pembelajaran yang dikembangkan di SMA Negeri 1 Sidomulyo. Hasil yang diperoleh dari kegiatan pengisian angket dan observasi menunjukkan bahwa sangat diperlukan sebuah alternatif untuk mengatasi keterbatasan media untuk penyampaian materi Termodinamika di sekolah. Selanjutnya dilakukan juga analisis kemampuan guru dalam penggunaan media TIK sebagai alternatif dalam penyampaian pembelajaran Termodinamika dengan hasil yang menunjukkan bahwa guru di SMA Negeri 1 Sidomulyo telah mampu menggunakan media TIK dengan baik serta di tambah sarana dan prasarana yang memadai dalam menggunakan media TIK.

Pengumpulan informasi dan pengolahan data yang diperoleh untuk menunjangan pengembangan media pembelajaran ini di dapat dari sumber yang relevan. Media pembelajaran ini adalah desain produk. Aplikasi yang digunakan untuk mengembangkan media ini adalah Adobe Flash Cs.6 yang memiliki kemampuan untuk menggabungkan unsur teks, gambar dan animasi dalam sekali penyajian. Beberapa hal yang dilakukan dalam mendisain produk ini diantaranya adalah penyesuaian produk dengan Kompetensi Inti dan Kompetensi Dasar sesuai dengan kurikulum 2013. Media pembelajaran disusun dengan konten isi didalamnya adalah pembuka, petunjuk, kompetensi, materi, evaluasi, referensi, dan profil.

a. Pembuka

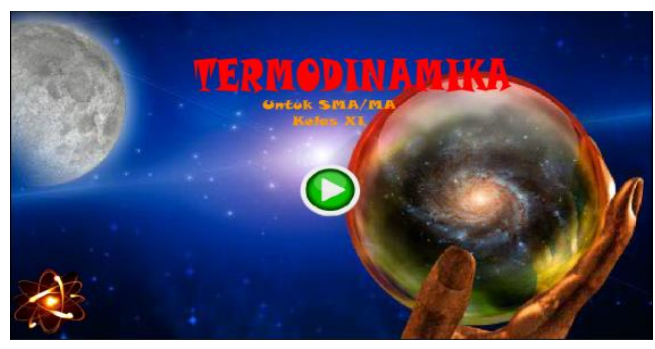

Gambar 1. Bagian awal media pembelajaran 
b. Petunjuk

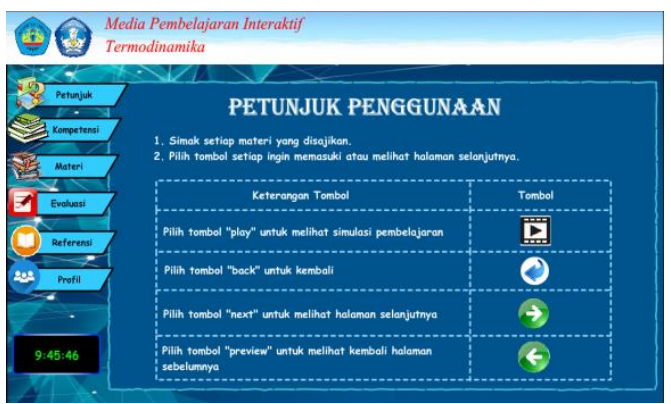

Gambar 2. Petunjuk penggunaan

c. Kompetensi

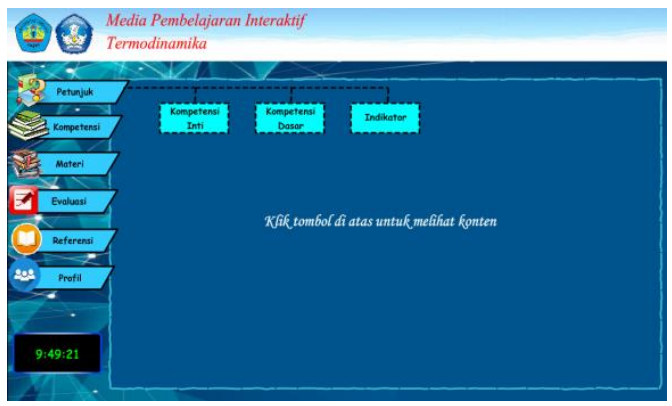

Gambar 3. Berisi konten KI, KD, dan Indikator

d. Materi

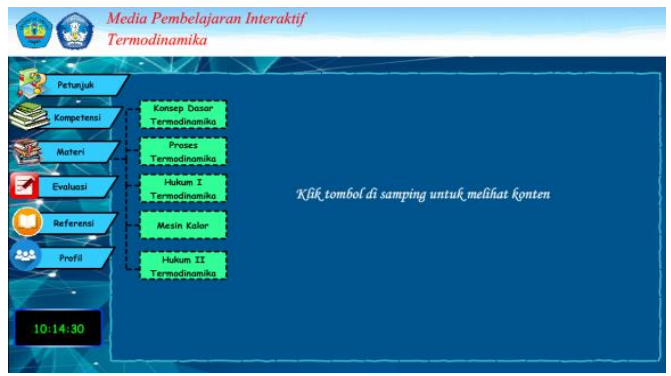

Gambar 4. Berisi konten materi 
e. Evaluasi

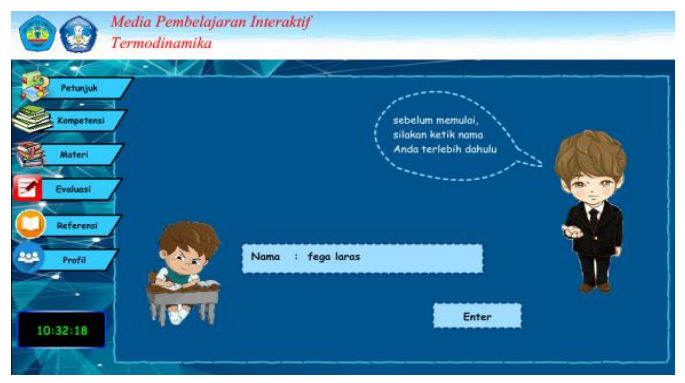

Gambar 5. Bagian awal evaluasi

Tahap validasi desain media pembelajaran dilakukan dengan 2 tahap validasi uji ahli materi dan uji ahli desain, dengan hasil uji ahli materi bertujuan untuk mengevaluasi isi materi, kelengkapan dan kesesuaian materi yang dikembangkan sesuai dengan kompetensi dasar. Uji validitas oleh pakar mengarah pada kesimpulan saran bahwa produk harus memberikan contoh aplikasi pada mesin 2 tak, 4 tak dan diesel menggunakan animasi pada system pembakaran mesin. Grafik dibuat dengan warna yang berbeda dan animasi perubahan variabel serta perbaikan mengenai warna tulisan di keterangan dan tabel petunjuk penggunaan.

Uji coba produk bertujuan untuk mengetahui kemudahan, kemenarikan, dan kemanfaatan dalam pemakaian produk. Pada ini dipilih tiga orang siswa yang dapat mewakili populasi target dari media yang dibuat. Uji coba produk ini dilakukan dengan cara memberikan angket kepada siswa. Hasil uji coba produk ini memiliki skor sebesar 3,52 dan saat di konversi menjadi pernyataan nilai kualitas produk ini memiliki nilai yang sangat menarik.

Hasil uji coba produk untuk mengetahui nilai kemenarikan media pembelajaran pada materi termodinamika, diperoleh hasil yang sangat menarik Skor yang diperoleh untuk uji kemenarikan adalah 2,93 sedangkan untuk uji kemudahan skor yang diperoleh 3,26 dan untuk uji kemanfaatan diperoleh skor 3,34. Keefektifan media pembelajaran dinilai sebanyak $84,62 \%$ siswa telah tuntas atau mencapai nilai KKM sehingga produk ini dapat dikatakan efektif untuk digunakan sebagai media pembelajaran.

\section{B. Pembahasan}

Media pembelajaran yang dibuat menggunakan Adobe flash Cs. 6 dapat disajikan dengan menarik dengan konten isi materi, gambar, animasi, dan contoh soal serta evaluasi pembelajaran dengan soal-soal interaktif didalamnya. Media pembelajaran yang dibuat telah melalui beberapa tahapan proses salah satunya proses pengujian yang meliputi: uji ahli materi, uji ahli desain, dan uji satu lawan 
satu. Ketiga proses ini telah dilalui, dan terdapat saran perbaikan untuk media pembelajaran seperti yang sudah diterangkan di hasil penelitian. Kemudian, media pembelajaran ini direvisi atau diperbaiki sesuai dengan saran yang sudah diterima sehingga media pembelajaran ini siap untuk di uji cobakan pada siswa.

Media pembelajaran yang dikembangkan diuji tingkat kemenarikannya dengan menggunakan angket. Hasil untuk uji kemenarikan diperoleh skor rata-rata 2.93 dengan kategori menarik. Media yang dikembangkan juga diuji untuk mengetahui tingkat kemudahannya dengan cara membagikan angket kepada siswa. Hal ini sesuai dengan kriteria penilaian akhir media uji kemenarikan yang dikembangkan oleh Suyanto [6]. Hasil uji kemenarikan menggunakan media ini sesuai dengan manfaat yang diperoleh dari pembelajaran menggunakan media yang dijabarkan oleh Arsyad [1].

Hasil untuk uji kemudahan ini diperoleh skor 3,26 dengan kategori media pembelajaran ini sangat mudah untuk digunakan. Kemudian untuk mengetahui kemanfaatan media dalam proses pembelajaran juga dilakukan uji dengan menggunakan angket yang diberikan kepada siswa. Hasilnya, media yang dikembangkan memiliki skor sebesar 3,34 dengan kategori sangat bermanfaat. Pengembangan media pembelajaran ini dapat meningkatkan dan mengarahkan perhatian siswa sehingga dapat menimbulkan motivasi siswa dalam belajar, interaksi yang lebih langsung antara siswa dan lingkungannya, dan kemungkinan siswa untuk belajar sendiri-sendiri sesuai dengan kemampuan dan minatnya.

Keefektifan dari media pembelajaran yang dikembangkan diujicobakan pada 39 siswa kelas XI IPA 4 saat siswa mempelajari pokok bahasan teori kinetik gas dan termodinamika. Keefektifan diperoleh dari hasil post-test siswa setelah menggunakan produk dengan mengerjakan soal-soal uji kompetensi yang terdapat di dalam media pembelajaran. Jumlah siswa yang tuntas KKM sebanyak 33 siswa dan jumlah siswa yang tidak tuntas KKM sebanyak 6 siswa. Dari data tersebut diperoleh presentasi $84,62 \%$ siswa telah tuntas KKM dan sebesar 18,38\% siswa belum tuntas KKM. jika 75\% siswa telah tuntas KKM, maka media pembelajaran dapat dikatakan efektif sebagai sumber belajar.

Hal ini relevan dengan penelitian yang telah dilakukan oleh Setiawati [7] dengan judul "Pengembangan Media Pembelajaran Interaktif Berbasis Teknologi Informasi dan Komunikasi Pada Materi Kemagnetan", dihasilkan media pembelajaran dengan keefektifan melalui post-test, ketercapaian KKM siswa dari hasil post-test mencapai lebih dari $75 \%$ yaitu sebesar $91,30 \%$. Dapat dikatakan media pembelajaran sangat efektif sebagai sumber belajar. Penelitian pengembangan ini juga didukung oleh penelitian yang telah dilakukan oleh Andre [8] dengan judul "Pengembangan Media Pembelajaran Berbasis Teknologi Informasi dan Komunikasi Pada Materi Hukum Newton Tentang Gravitasi dengan Pendekatan Saintifik" yang memperoleh hasil keefektifan media pembelajaran memalui pengerjaan soal-soal uji kompetensi yang terdapat dalam produk prototipe II, dengan ketercapaian KKM siswanya lebih dari $75 \%$ yaitu sebesar 78,94\%. Media pembelajaran ini dapat dikatakan sebagai media yang efektif sebagai sumber belajar. 
Media pembelajaran yang dikembangkan ini, menyajikan fenomena yang sesuai dengan konsep yang ini disampaikan. Fenomena yang berkaitan dengan termodinamika, divisualisasikan dengan sedemikian rupa seperti proses yang terjadi. Proses-proses dalam termodinamika yang ditemui dalam kehidupan seharihari divisualisasikan secara ideal dengan menggunakan gambar, dan video animasi yang terdapat dalam media pembelajaran sehingga pemahaman konsep dapat dilakukan dengan cara yang lebih menarik. Media pembelajaran ini disajikan dengan format .swf yang dapat di putar dengan menggunakan pemutar media yang umum terdapat pada perangkat komputer. Media pembelajaran ini, di publikasikan ke dalam CD yang dapat langsung diputar di laptop maupun komputer. Hal ini diharapkan memberikan kemudahan bagi pengguna media pembelajaran. Media pembelajaran ini merupakan media interaktif sehingga pengguna dapat berinteraksi dengan materi pembelajaran yang disajikan serta dilengkapi dengan gambar dan simulasi pembelajaran untuk memudahkan pengguna memahami isi pesan pembelajaran. Hal ini sesuai dengan pernyataan Gagne dalam Sadiman, dkk [9] menyatakan bahwa media adalah berbagai jenis komponen dalam lingkungan siswa yang dapat merangsangnya untuk belajar.

Program yang digunakan untuk membuat media pembelajaran ini belum memungkinkan untuk menambahkan persamaan-persamaan Hukum Termodinamika karena belum terdapat fitur equation seperti pada program $M s$ Word sehingga untuk menambahkan persamaan harus dikonversikan ke dalam format JPEG, $P N G$ atau format lain yang mendukung. Keterbatasan tersebut mengurangi nilai estetika dan keserasian tampilan khususnya pada tampilan yang memuat persamaan yang tidak dapat dituliskan secara langsung menggunakan Text Tool. Disamping itu, media pembelajaran ini baru diujikan pada kelompok skala kecil sehingga belum benar-benar teruji keefektifannya untuk kelompok skala besar. Dalam media ini kurang menjelaskan untuk memecahkan soal-soal yang bersifat prosedural (hitungan) sehingga siswa harus dituntut berlatih soal yang sifatnya prosedural di rumah.

\section{SIMPULAN DAN SARAN}

Dihasilkan media pembelajaran interaktif bebasis TIK dengan materi pokok Termodinamika dan telah dilakukan uji dengan kualitas: sangat mudah digunakan, mearik dan sangat bermanfaat sebagai sumber belajar menurut pengguna.

Disarankan kepada peneliti pengembangan lebih lanjut untuk dapat memperbaiki media pembelajaran dengan menambahkan konten-konten yang mendukung pembelajaran seperti penulisan persamaan matematis.

\section{DAFTAR PUSTAKA}

[1] Arsyad, Azhar. 2011. Media Pembelajaran. Jakarta : PT Raja Grafindo Persada 
[2] Setyono, Yulian Adi, Sukarmin, dan Daru Wahyuningsih. 2013. Pengembangan Media Pembelajaran Fisika Berupa Buletin dalam Bentuk Buku Saku Untuk Pembelajaran Fisika Kelas VIII Materi Gaya Ditinjau Dari Minat Baca Siswa. Jurnal Pendidikan Fisika, Vol.1(1) : 118-126.

[3] Imunandar, Farhan dan Umi Khayatun Mardiyah, Siti. 2016. Pengembangan Multimedia Pembelajaran Berbasis Adobe Flash Pada Standar Kompetensi Memproses Perjalanan Bisnis Untuk Sekolah Menengah Kejuruan (Smk) Kompetensi Keahlian Administrasi Perkantoran. http://eprints.uny.ac.id/id/eprint/43468

[4] Yusuf., Andi, Momang,. 2015. Pengembangan Media Pembelajaran Berbasis Adobe Flash Untuk Mata Kuliah Fisika Modern Materi Radiasi Benda Hitam. Jurnal Sains dan Pendidikan Fisika, Jilid 11, Nomor 1, April 2015, hal. $57-71$.

[5] Sugiyono. 2014. Metode Penelitian Pendidikan, Pendekatan Kuantitatif, Kualitatif, dan $R \& D$. Bandung : Alfabeta.

[6] Suyanto, Eko dan Sartinem. 2009. Pengembangan Contoh Lembar Kerja Fisika Siswa dengan Latar Penuntasan Bekal Awal Ajar Tugas Studi Pustaka dan Keterampilan Proses untuk SMA Negeri 3 Bandar Lampung. Prosiding Seminar Nasional Pendidikan 2009. Bandar Lampung. Unila.

[7] Setiawati, Dewi. 2013. Pengembangan Media Pembelajaran Interaktif Berbasis Teknologi Informasi dan Komunikasi Pada Materi Kemagnetan. Bandar Lampung : Unila (diterbitkan)

[8] Andre, Edo Larichie,.2014. Pengembangan Media Pembelajaran Berbasis Teknologi Informasi Dan Komunikasi Pada Materi Hukum Newton Tentang Gravitasi Dengan Pendekatan Saintifik. Bandar Lampung : Unila (diterbitkan)

[9] Sadiman, Arif S, R Raharjo, Rahardjito, dan Anung H. 2008. Media Pendidikan Pengertian, Pengembangan dan Pemanfaatnya. Jakarta: PT Raja Grafindo Persada. 